\title{
A spatial analysis of precariousness and the gender wage gap in Mexico, 2005-2018
}

\author{
Roldán Andrés-Rosales ${ }^{1}$, Lukasz Czarnecki ${ }^{2 *}$ (1) and Miguel Ángel Mendoza-González ${ }^{3}$
}

\author{
* Correspondence: lukasz@ \\ comunidad.unam.mx \\ ${ }^{2}$ CONACYT-SNI1, National \\ Autonomous University of Mexico, \\ Av. Universidad 3000, CP 04510 \\ Mexico City, Mexico \\ Full list of author information is \\ available at the end of the article
}

\begin{abstract}
The North American Free Trade Agreement (NAFTA) between Canada, Mexico, and the USA (1994-2018) has led to a reorganization of the productive structure of Mexico's 32 metropolitan areas, affecting what jobs are offered in the country's regions. This includes tertiary activity, which determines most employment in metropolitan areas. Most employment in this sector, however, is more precarious than in the secondary sector. Additionally, women participate in this sector more than men, exacerbating wage inequality. Based on data from the National Survey of Occupation and Employment (ENOE in Spanish), we analyze the income gap in Mexico's metropolitan areas. We find that inequality is exacerbated in less developed areas in which the tertiary sector predominates. Moreover, the decrease in the labor gap is caused by the precariousness of working conditions.
\end{abstract}

Keywords: Labor inequalities, Precariousness, Spatial analysis, Mexico

Jel classification: J3, J7, R0

\section{Introduction}

Since Mexico entered NAFTA in January 1994, the Mexican economy has been spatially restructured. The transformation to a market-oriented development paradigm had an impact on the reconfiguration of Mexico's occupational sector. The concentration of economic agents, companies, and consumers is not a random process, but rather reflects the characteristics of a particular region, as well as its natural, social, and competitive advantages. For example, spatial labor sorting-analyzed by theorists like Combes, Duranton, and Gobillon-has been applied by researchers such as ChaconEspejo and Paredes (2015) to suggest that the most qualified consumers tend to migrate to regions where there is a greater concentration of economic activity and more competitive advantages. Likewise, individuals relocate to places that offer the greatest variety in consumption (Glaeser 1999; Glaeser and Mare 2001; Chacon-Espejo and Paredes 2015) and urban amenities (Florida 2002).

Within the New Economic Geography (NEG), not all regions can concentrate on economic activity; thus, there are variations between them and their levels of development. This has led to inequality, both between and within regions. Opportunities in certain regions have not only attracted qualified personnel but have also made it possible for companies to relocate to such places (Moretti 2013). This reinforces spatial

(c) The Author(s). 2019 Open Access This article is distributed under the terms of the Creative Commons Attribution 4.0 International License (http://creativecommons.org/licenses/by/4.0/), which permits unrestricted use, distribution, and reproduction in any medium, provided you give appropriate credit to the original author(s) and the source, provide a link to the Creative Commons license, and indicate if changes were made. 
inequality, as higher productivity increases local nominal wages (Chacon-Espejo and Paredes 2015). Not all workers have access to high-paying jobs, and most experience inequality. This holds in all regions and is exacerbated by local market development. Labor precariousness is also prevalent throughout Latin America (Fernández and Sotelo 2013).

Mexico has gone through various development models, from growth based on mineral extraction (i.e., silver and gold) and Indian labor, to feudal agriculture in the nineteenth century (Villamarin and Villamarin 1975). During the Mexican Revolution of 1917, the question of the peasantry was on the agenda. It was president Lazaro Cardenas (r. 1934-1940), however, who introduced legal provisions in terms of labor protections and the nationalization of natural resources. Development was suppressed by a period of "industrialization by import substitution" ("ISI" in Spanish) that lasted three decades after the end of the Second World War. During this period, the secondary sector (manufacturing activities) was considered the central axis of growth during the "Golden Age" of the postwar industrialization period, a time known for its "stable development" (desarrollo estabilizador).

Starting from the 1980s, the manufacturing industry, which had been considered an engine for growth (Kaldor 1984), began to modify its commercial, productive, investment, and employment frameworks (Carbajal and De Jesús 2017). Additionally, throughout this period, tertiary activities (services) began to develop. It was not until the 1990s, however, that most tertiary activities developed. Under President Salinas de Gortari (r. 1989-1994), Article 27 of the Mexican Constitution was changed. This permitted land marketing and suppressed common land ownership known as "ejido" (Perramond 2008). The trend toward rural-to-urban migration created opportunities for employment in urban areas. Today, as in the international economy, the tertiary sector determines most of the employment opportunities generated in various metropolitan areas. Most employment in this sector, however, is more precarious than that of the secondary sector. Female participation is also greater, with more wage inequality in the tertiary sector than in the secondary sector.

In addition, Mexico has experienced weak economic growth, meanwhile, neoliberal policies had detrimental consequences in salaries and employment conditions (Czarnecki and Vargas-Chanes 2019). This has led to a scarcity of employment opportunities, greater precariousness, and job insecurity in areas in which the female labor force has grown. An unfortunate coincidence has resulted: the increasing number of women in the labor market has been accompanied by a deterioration of their working conditions (García 2009). This transformation has had distinct impacts in various regions.

Slow growth tends to be accompanied by job precariousness. Within the period analyzed (2005-2018, using INEGI's information), the observed average GDP growth was $2.24 \%$. For the manufacturing sector, the secondary sector and the tertiary sector, growth was $1.7 \%, 0.77 \%$, and $2.95 \%$, respectively. The tertiary sector grew more than the secondary sector.

This paper addresses the following questions: is there greater precariousness in Mexico's secondary sector than in its tertiary sector? Is female work more precarious than male work? What factors determine the gender labor gap? Does labor precariousness determine the gender wage gap? We analyze the conditions in which increases in income inequality are accompanied by increased labor precariousness in the 32 Mexican 
metropolitan areas. ${ }^{1}$ We also asses which sectors had the greatest impact on the precariousness and the wage gap. Based on these questions, we propose the following hypothesis: regional inequality exacerbates labor precariousness and wage inequality between men and women in Mexico. In addition to the slow growth of the different sectors, women have fewer non-precarious employment opportunities than men.

This labor precariousness has led us to analyze how the wage gap responds to the precarious labor situation in Mexico's various productive sectors. Given the importance of the tertiarization that has occurred in recent years, we focus on two economic sectors: manufacturing and the tertiary. From this perspective, we study labor inequalities and increased precariousness for men and women in Mexico's principal metropolitan areas. We analyze the metropolitan areas in which the stratification and expansion factors are significant. Moreover, we are interested in labor inequality in urban-but not rural-areas; this is because more than $80 \%$ of economic activity takes place in large cities and not in rural areas (Asuad 2001). Furthermore, data on Mexican rural areas are insufficient and unreliable.

This article is divided into three sections. The first analyzes increased labor precariousness and the sexual division of labor. The second describes the data and exploratory analysis used; and in this section, we analyze which regions have the highest labor precariousness, while also performing a regional analysis by activity sector. We also determine which regions' metropolitan areas have the greatest gender income gaps. In the third section, we propose an econometric model and provide the main findings obtained from empirical evidence. We compare these results with other research done on the Mexican economy. In the third section, we also present public policy proposals for the existing problems of increased precariousness and the sexual division of labor.

\section{Regional inequalities}

Labor precariousness worsens inequality, and both are more acute in regions with less economic development. Inter-regional inequality is due to a net outcome between the centripetal forces of geographical concentration and the centrifugal forces of dispersion (Kim 2008; Chacon-Espejo and Paredes 2015). According to the NEG, "the concept of agglomeration economies and its relationship with spatial economic performance has a central role" (Camagni et al. 2015: 133). Agglomeration economies, seen as "the pervasive influence of some kind of increasing returns" (Krugman 1991: 5) exemplify what Krugman (1991: 11) calls a "cumulative process of regional divergence."

This agglomeration of activities is the main force behind the creation of big cities (Camagni et al. 2015). Within this neoclassical vision, there is an economic equilibrium at all levels, which is to say that everyone has the same opportunities in terms of salaries, employment, etc. According to this traditional approach, salaries, and incomes are in balance, given the existence of perfect competition.

According to the NEG, perfect competition does not exist; the same regional advantages give rise to the concentration of economic and demographic activities, which are greater than those in remote and poor areas. The urban economy, however, highlights the importance of workers' heterogeneity and geographic locations. The theory of spatial labor sorting suggests that the concentration of human capital in large cities translates into greater inequality of productivity and income (Chacon-Espejo and 
Paredes 2015) between different metropolitan areas. When internal factors are weak regionally, the domestic market will also be weak. Therefore, lower wages are offered and working conditions are precarious (Camagni et al. 2015). In addition, in such regions, the links among companies are almost non-existent, which makes these regions more vulnerable and more disadvantaged than others.

Mexico has different manufacturing and service sectors in its diverse metropolitan areas. The importance of economic growth means greater labor participation for persons of working age, while slow growth exacerbates unemployment and informality (García 2009). The response of the population to this adverse economic environment is to leave the labor market, thus becoming unemployed or working in the informal sector.

Nevertheless, Mexico's economic growth has failed to fully utilize its natural resources, limiting the productive potential of its regions, exacerbating social exclusion (AndrésRosales et al. 2018) and poverty (Cruz 2013), and worsening inequality (Murphy and Welch, 1993; Wolff 2001). The underutilization of productive resources is one cause of wage inequality in Mexico. Some authors agree, however, that factors such as human capital (Schultz 1961; Becker 1975; Brown et al. 1999), as well as the experience and skills acquired by workers (Wolff 2006; Forida et al. 2011), have had the most influence on inequality. These factors can be magnified by labor market imperfections, such as monopsony, poor information, and geographical immobilities (Argy 2007). The literature, however, shows that the spatial impacts on wages center on differences along four dimensions (Zhou 2016): the local composition of skills, local returns on skills, differences in costs of living and locational amenities, and differences in local labor market conditions.

The productive structures of the various regions are the final determinant of the development of skills that some theorists consider a principal cause of inequality. The slow growth of the productive system tends to exacerbate the problems that afflict the different regions, and among them, wage inequality for women. In this regard, Rodríguez-Pérez and Castro-Lugo (2014), using Hanson's classification (Hanson 2005), argue that with the opening up of commerce this inequality could have diminished. This is because regions with more ties to the USA could have improved their working conditions. Meanwhile, regions with fewer links to this market could have seen increases in wage inequality (Rodríguez-Pérez 2018).

According to Porciles et al. (2007), high wages are a result of the labor force's education level and are accompanied by an increase in worker health and increased competitiveness. In turn, this generates a virtuous cycle of growth, which implies greater human capital, competitiveness and worker productivity, and, as a consequence, higher effective demand. The case of the Mexican economy, however, has been the opposite: greater precariousness within the labor force generated by slow economic growth and a weak internal market has exacerbated social exclusion (Andrés-Rosales et al. 2018).

\section{Labor precariousness}

Labor precariousness refers to the instability and lack of legal protection of wagepaying occupations. Labor precariousness appears as an attribute of the link between employees and employers (Andrés-Rosales and González 2012). It involves multiple elements such as instability, lack of medical and social protection, insecurity, low wages, and social and economic vulnerability. Nevertheless, unstable employment is not 
necessarily precarious; it is a combination of these factors. The multiplicity of forms of precarious labor leads to the fragmentation of the working base. According to Caire (1982: 136), "precarious employment is defined by its opposition to typical employment." The latter is characterized by its indeterminate duration and the existence of a contract concluding with a single identifiable employer. On the contrary, precarious employment impacts both the nature of the contract, as well as the full identification of the employer. The different manifestations of precarious employment include the following characteristics: (i) informal work, (ii) certain forms of work from home, (iii) apprenticeships, (iv) contracts for fixed durations, (v) contracts that are not regular, (vi) work found through temp agencies, (vii) work based on subcontracting (outsourcing), and (viii) part-time work.

Salvia and Tissera (2000) argue that the definition of precarious work must involve at least three common elements: (1) instability, (2) illegality, and (3) lack of protection. Marshall (in Salvia and Tissera 2000) uses the concept of uncertain employment, which he defines as an employment relationship where there is permanent uncertainty over the continuity of the worker's employment. In addition to temporary contracts that comply with legal regulations, it can be observed that temporary employment evades (either partially or in full) the obligations set by labor legislation. Rubery (1989) suggests taking into account aspects such as (a) the system of labor regulation, (b) structure and industrial organization, (c) characteristics of the labor market, (d) the system of social reproduction, and (e) social welfare policy. According to Caamaño (2005), atypical work refers to all employment contracts that do not fall within the model of a normal work relationship (i.e., those that are not legally regulated or that do not meet all the characteristics of a normal employment relationship).

Labor precariousness includes multiple dimensions (Rogers 1989). The first refers to the degree of certainty with respect to the continuity of a job. According to Rodgers, precarious jobs often have short durations and a high risk of dismissal. The second dimension includes the control over work; the less the worker controls-either individually or collectively-his labor, salary, or working conditions, the more tenuous is the continuity of his or her employment. The third and most important dimension refers to social protection. This is a crucial aspect, and it refers to the extent to which workers are protected by law or collective organizations. The final dimension, according to Rodgers, is ambiguous. This is because low incomes can be associated with precarious jobs, as long as they relate to an environment of poverty or unfavorable social positions. Not all unstable or insecure employment, however, should be considered precarious, since the particular combinations of the previously described dimensions are those that identify precarious jobs.

In the case of Mexico, Rojas and Salas (2008) suggest that precarious work implies high levels of poverty and the absence of unemployment insurance. Thus, the working age population creates its own employment through informal self-employed activities in either commerce or services, or accepts jobs without labor contracts. These jobs are temporary and lack social benefits.

This begs the question: what causes precarious work? Precarious work manifests itself in different situations and in different contexts, but it shares several common conditions: (i) employment insecurity and an uncertain future; (ii) low remuneration (which does not cover workers' basic needs, as well as those of his or her family); (iii) limited 
social benefits or none at all; (iv) work risks and unsafe conditions; (v) lack of health protection; (vi) lack of protection from accidents or sickness due to working conditions; (vii) loss of rights (for example, a lack of unions); (viii) constant threats of unemployment; and (ix) excessive work hours.

These conditions affect the health of workers, which aggravates their exposure to occupational risks. Each of these factors indicates that workers with temporary contracts have been assigned the worst tasks with unsatisfactory working conditions. In short, the precariousness of temporary jobs often leads to precarious working conditions.

\section{The wage gap}

The slow growth and productive structure of various metropolitan areas have been explained as such: "Women are mainly incorporated into the various branches of the tertiary sector, performing the typically female occupations of secretary, nurse, teacher, waitress and unskilled worker, among other personal services. Occupational gender segregation has unfavorable implications on female income levels and the possibilities for social mobility, and the same occurs with wage discrimination" (Oliveira and Ariza 2000: 644).

In addition, in the Mexican economy, trade liberalization has stimulated labor flexibility. This is not an isolated factor, as Standing (1999: 583) notes, "since 1970, the global economy has been in the era of market flexibility, in which new technology, new labor control systems and reformed forms of work organization have transformed patterns of labor force participation throughout the world." Unions, meanwhile, are the defenders of the few remaining labor rights. For example, today's flexibility has given rise to social and labor insecurity, within which men and women have been pushed into more precarious jobs, although it is women who incur the highest precariousness in less developed regions, as this study will show.

Within discussions on wage inequality, Puga (1999) argues that it is generated by the agglomeration of productive activities, which in turn cause regional inequality. According to her, these regional differences give rise to wage differentials, where the poorest regions are those that experience the most gender inequality. Lindley and Jinkins 2014: 121) suggest that the "wage differential is linked to education or experiences, emphasizing increases in the college wage premium or the wage return to experience that have gone hand-in-hand with rising wage inequality." The authors assume that there is a considerable wage difference, generated by both location and economic sectors. The general tendency described by the authors, however, is the polarization of highly skilled and unskilled jobs, where the former earn more than the latter. According to Farrokhi and Jinkins 2015: 6), "A worker is highly educated if he has a four-year college degree. The college premium is the mean wage of highly educated workers in a country divided by the mean wage of other workers. The college population share is the population of highly-educated workers in a country divided by the population of less-educated workers."

Quintana and Garza (2017) have analyzed the wage inequality of what they consider creative activities and non-creative activities. In their study, they show that there is a wage gap in the different regions of Mexico: where creative activities are the least precarious and also have more advantages in terms of remuneration and equality. This is because in these activities, there is a greater concentration of highly educated workers than in traditional sectors. They also found that wages have declined more in 
traditional sectors than in the creative sectors. While Quintana and Garza (2017) analyze the creative activities of Mexico's 32 federal entities, Mendoza-González et al. (2017) argue that wage discrimination toward women is more narrow when working hours are considered (as opposed to paid hours), given that women work fewer hours per month than men. This may also contribute to wage differences. Others have connected it to technological change, which tends to displace the workforce (RodríguezPérez et al. 2011).

\section{The sexual division of labor}

The sexual division of labor (Kergoat 2012; Pfefferkorn 2016) is a marker of gender inequality. According to these approaches, inequality is perpetuated by a system that is reproduced from generation to generation, according to gender differences in labor tasks. This produces wage gaps (Kergoat 1978; Czarnecki 2011a; Czarnecki 2011b). That is the reason for the use of the expression "the sexual division of labor" and not "the gender division of labor," as the former denotes biological differences while the latter implies socio-cultural roles of development. The sexual division of labor "studies the place of the sexes in the relations of production (in a broad sense) and in the social division of labor" (Kergoat 2012: 18). Meanwhile, the concept of "gender" does not reflect the power differential between the sexes, while "sexual division" encompasses social class and power differentials between the sexes.

According to the Dictionary of Inequalities, the concept of gender "cannot break up with the idea of nature that implies a division and hierarchism between men and women: it will be a 'cache-sex"' (Lépinard and Lieber 2015: 181). This is the reason why we prefer

the concept of the "sexual division of labor," which stems from the "social rapports ${ }^{2}$ of sexes" (Pfefferkorn 2016). This approach includes in its analysis an idea of antagonistic relations between men and women, power conflicts between them, and systematic reproduction from generational polarization (Bihr and Pfefferkorn 2015). Within this context, the discussion has returned to social class (Bouffartigue 2015). There are many commonalities between the relations between the sexes and the concept of social class. According to Dubet (2012: 259), "classes are defined by domination, exploitation, solidarity, and competition." This refers to the rapports between men and women.

\section{Spatial analysis: data and model \\ Data}

The data used in this study come from both the ENOE and the INEGI. This study used panel data from the metropolitan areas of self-represented cities from 2005 to 2018. It uses the first trimester of each year of the ENOE, because in this trimester extended INEGI survey results are presented. The economic sectors include the manufacturing industry, the rest of the secondary sector (extractive industries, electricity, and construction), the high-tertiary sector (commerce, dining, accommodation services, transport, communications, mail and storage, professional, financial, and corporate services), and the low-service sector (social services, diverse services, government, and international organizations).

The main variables are men's and women's average hourly incomes and full workday. Additionally, following the methodology of Mora (2012), the precariousness index includes (i) the employed population that has no social benefits, (ii) those earning equal 
or less than two minimum wages, and (iii) those without labor or non-union contracts. Data was obtained from the ENOE. The precariousness index was developed based on the proportions of the population with these given characteristics. It is important to note that the Cronbach's Alpha test, which measures the internal consistency of a composite index (Mora 2012), was used to construct this index. ${ }^{3}$

In addition, the construction of the wage gap variable was made via a methodology in which the income differential by gender uses the natural logarithm of labor ${ }^{4}$ :

$$
\hat{\Delta}_{y}^{\mu}=\ln \overline{\mathrm{Y}}_{h}-\ln \overline{\mathrm{Y}}_{m}=\ln \left(\overline{\mathrm{Y}}_{h} / \overline{\mathrm{Y}}_{m}\right) \text {, between men }(h) \text { and women }(m) \text { (Mendoza- }
$$

González et al. 2017), in the same way, we treated the exogenous variables. The output shows that the average income of men is higher than that of women. Multiplying this result by 100 provides a percentage.

\section{Spatial analysis of inequality and precariousness}

Given the change in the growth model of the Mexican economy, the reconfiguration of the productive structure in the different regions has created employment heterogeneity. Precariousness is more acute in some metropolitan areas than in others. At the aggregate level, we find that the average growth of employed persons decreased by $-0.38 \%$ in the period from 2005 to 2018. The number of men employed in this period also showed a decrease of $-0.88 \%$, while the number of employed women increased by $0.38 \%$. The number of persons employed in the manufacturing sector also decreased by $-0.74 \%$. Of the men and women employed in this sector, their average decreases were $-1.02 \%$ and $-0.17 \%$, respectively. The employed population in the services sector showed an average decrease of $-0.43 \%$, with the number of men decreasing by $-1.10 \%$ and the number of women growing by $0.33 \%$. In the high service sector, the average decrease was $-0.10 \%$, with the number of men decreasing by $-0.71 \%$ and the number of women increasing on average by $0.79 \%$ (according to data from the National Survey of Occupation and Employment, INEGI). We observed that job growth was slightly larger among women in higher level services. If we analyze this employment growth in metropolitan areas, we find that the average increase in employed people of the highest tertiary sector was in Tepic at $4.7 \%$, followed by Tlaxcala at $3.9 \%$, Campeche at $3.5 \%$, and Tuxtla Gutierrez and La Paz at 3.3\%.

Large companies and transnational corporations concentrate in Northern Mexico where "the economic dynamics of border cities are related to the disturbances of the world market, specifically with the economy of the United States, since the majority of direct foreign investment and exports find their origin and destination respectively in that country" (Castro et al. 2018: 46). The greatest concentration of economic and population activity, however, is found in Central Mexico. For example, of Mexico's 123, 518,270 inhabitants in 2017, according to the CONAPO, $14 \%$ were concentrated in the State of Mexico, 7\% in Mexico City, 6.6\% in Veracruz, 6.5\% in Puebla, and 5\% in Guanajuato. In addition, the highest concentration of GDP was in Mexico City (17\%). The State of Mexico had almost 8\%, and Nuevo Leon and Jalisco each had nearly 7\%.

Figure 1 shows the spatial distribution of precarious work in the manufacturing sector. The shaded part of the map represents entities that have greater precariousness in the manufacturing sector, while the white part represents entities incurring little precariousness. The black and white bars that stand out from the different metropolitan 
areas represent the precarious work of men and women, respectively, in 2018, showing if precariousness is equal, less or greater between men and women. Manufacturing employment in Mexico is concentrated in the Center and North of the country, but as shown in Fig. 1, employment in the central and southern parts of the country is more precarious than in most of the northern areas.

This difference in precariousness is partly is explained by the fact that women are in higher demand by the maquilas sector in Northern Mexico. According to Castro et al. (2018: 48):

The maquiladora program was created in order to combat unemployment [and was] derived from the expulsion of workers from the North American fields (mostly men). [The] maquiladora industry was characterized from its beginning by the incorporation of the predominantly [female] labor force. [This is because] employers generally agree that this type of workforce...given their patience and manual dexterity...can perform assembly operations and are willing to endure work routines imposed by male staff.

In addition, the economic sectors in the northern border areas have evolved with respect to hiring, while the industries typically turned female in the industrial development model have become less female (Dela et al. 2002).

The explanation for this lies within the fact that changes within the maquila diversified the most sophisticated and technical production processes. This was caused by the opening up of commerce and because such areas could be considered "high exposure," as described by Rodríguez-Pérez and Castro-Lugo (2014). Hence, modifications are being made in the structure of specific occupations and the type of products generated by

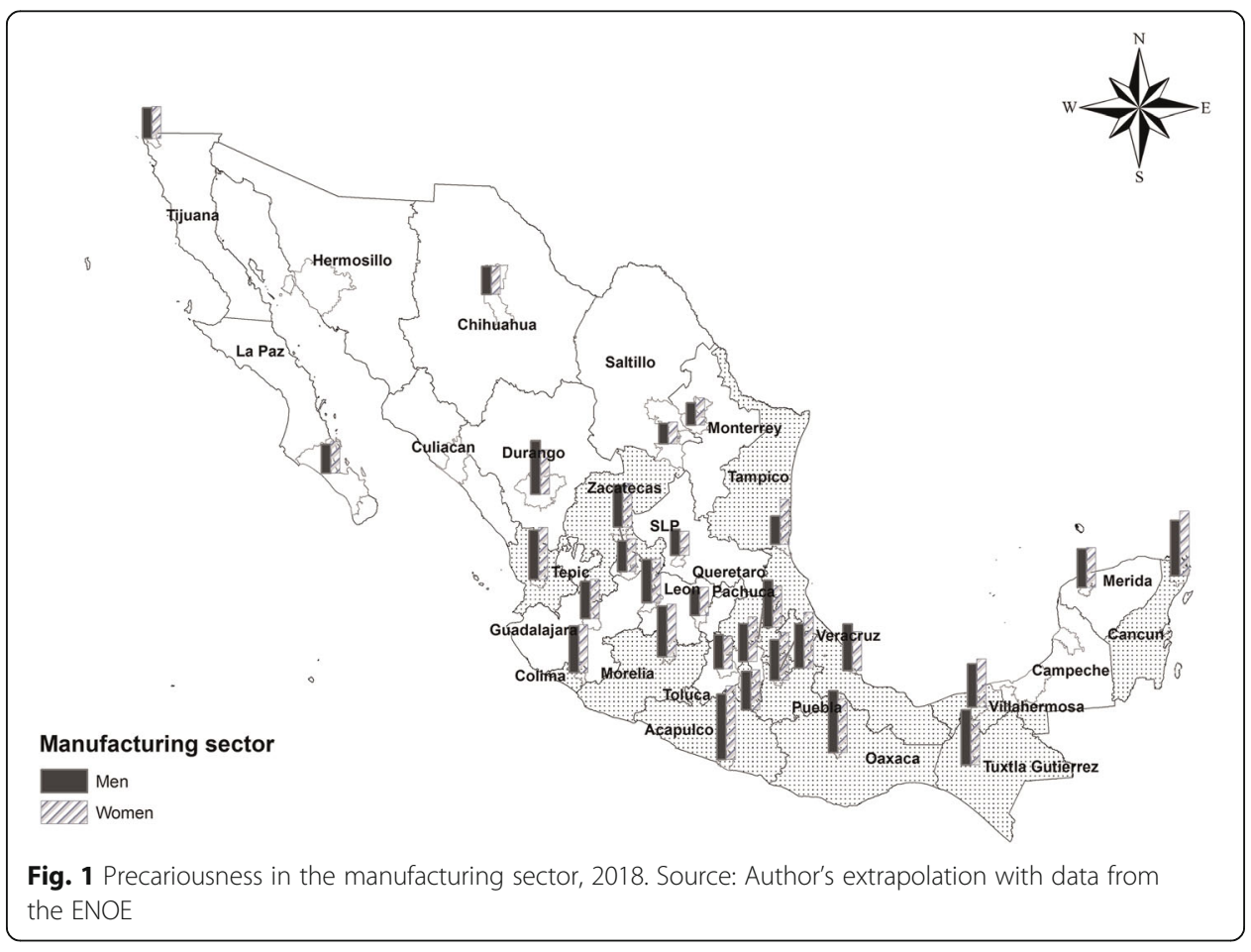


these branches, particularly in North America, including branches such as transportation (automotive and parts) and electronics (Jiménez 1989; Castro et al. 2018). Thus, we observe less job insecurity here than in the central and southern regions of the country.

Considering the rest of the secondary sector, Fig. 2 shows the precariousness of both men and women. The observed precariousness of men is greater than that of women. Moreover, this sector offers more precarious employment than the other sectors, given that the shaded part covers more entities than in Fig. 1.

Figure 3 shows that precariousness is lower in the high-tertiary sector than it is in the other sectors, including the low-tertiary sector. In addition, we observe that differences in precariousness between men and women are minimal. This is a sign that persons who work in the branches of commerce, dining, accommodation services, transportation, communications, mail and storage, and professional, financial, and corporate services have better working conditions than those of the rest of the sectors analyzed. At the very least, they-both men and women-have less precarious jobs.

Finally, within the low-tertiary sector, we find that precariousness is greater among women than men. In addition, it is larger in the southern and central regions of the country than in the North. We confirm that women have to work in the tertiary sector, which offers jobs that are both low-paid and precarious (Fig. 4).

As of 2018, the concentrations of the employed population in both the manufacturing and the high-tertiary sector have dispersed. It is important to note that service sector concentrations have dispersed to several regions, while the manufacturing sector has remained more concentrated. It is noteworthy, however, that the manufacturing sector remains slightly more polarized, as its concentration of male employment is slightly higher than that of women.

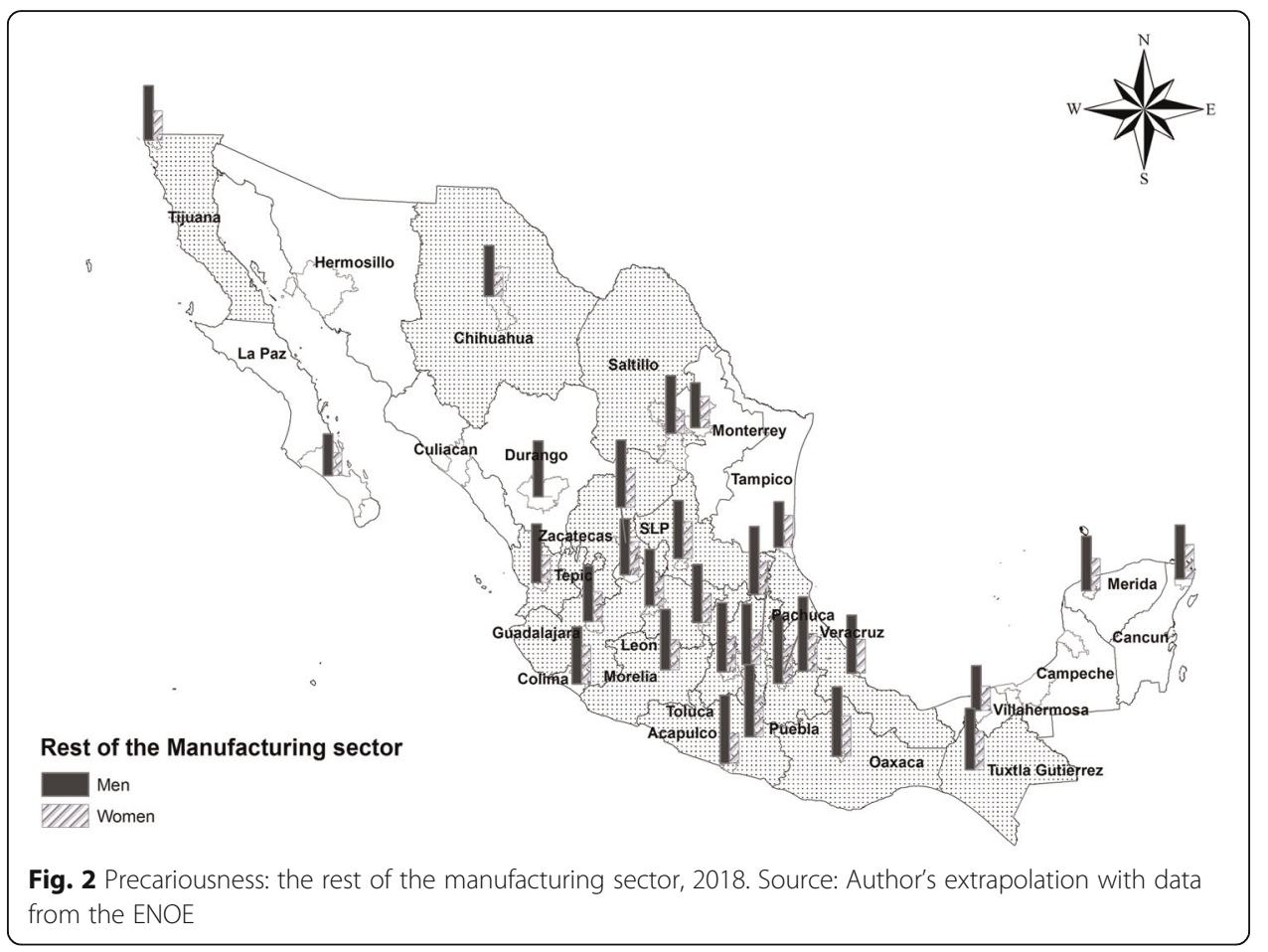




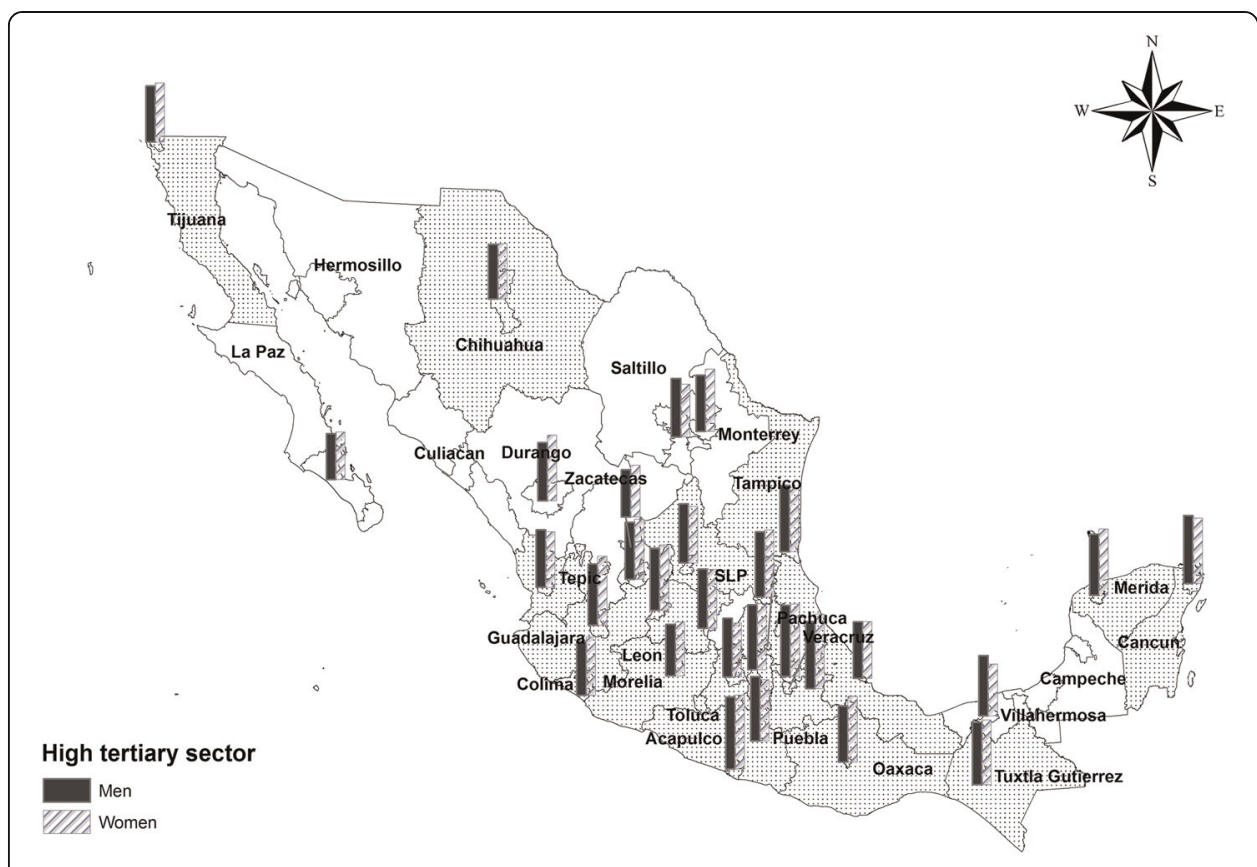

Fig. 3 Precariousness in the high-tertiary sector, 2018. Source: Author's extrapolation with data from the ENOE

Low tertiary sector

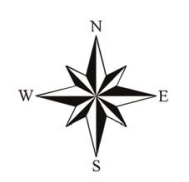

Fig. 4 Precariousness in the low-tertiary sector, 2018. Source: Author's extrapolation with data from the ENOE 
The distribution of human capital in these sectors is concentrated in the more dynamic regions, which have higher levels of economic activity. That is, the first difference in the wage gap is related to disparities in training, but the second is precisely because of differences in the concentration of productive structures, which reproduces vicious or virtuous cycles. In developed countries, productivity determines wage levels. In countries like Mexico, however, they are determined more by politics and by the limitations of its productive structures than by productivity itself. This implies that given a scarce supply of employment opportunities, it is difficult for well-trained persons to find good jobs. When they do, their salaries are below market value. Mexico has a high unemployment rate. Therefore, workers are willing to accept salaries even when they are below what they should be earning. Additionally, there are subcontracts at the national level which degrade work. Although it is true that they are more productive in the sense of being more efficient, it is also true that these are more precarious jobs. That is, "a key issue is whether these benefits stem from the size of the overall market (urbanization economies) or from geographic concentrations at the industry level (localization economies)" (Combes et al. 2008: 724).

\section{Model}

To estimate the wage gap, we include endogenous and exogenous variables. These are taken from previous studies such as McCall (2001), who uses as an endogenous variable the hourly wage $(i)$ in a region $(j)$ calculated from annual earnings divided by the number of weeks worked.

On the other hand, Mendoza-González et al. (2017), as well as Fortin et al. (2011) use the estimated average labor income differentials between men and women as an endogenous variable. In this model, the exogenous variables include human capital (years of average schooling, years of experience, and hours per week devoted to training and/or studies for men and women). Like the previous proposals, we use income differentials and propose our model following the approach of Rodríguez-Pérez and Castro-Lugo (2014):

$$
\begin{aligned}
& \ln \left(\overline{\mathrm{Y}}_{h} / \overline{\mathrm{Y}}_{m}\right)=\rho W y+\beta_{1} \ln (\text { iprec })+\beta_{2} \ln (\text { escolar })+\beta_{4} \ln (\text { prim })+\beta_{6} \ln (\text { secund }) \\
& +\beta_{7} \ln (\text { tert })+\beta_{8} \ln (\text { exp })+\beta_{9} \ln (\text { cap })+\beta_{10} \ln (\text { labprop })+\varepsilon_{\mathrm{t}}
\end{aligned}
$$

The exogenous variables include the logarithmic means of the labor precariousness index (iprec), schooling (escolar), degree (primary, secondary, tertiary) for men and women, experience (exp), training (cap), occupation (labprop), and error.

The endogenous variable is the natural logarithm of labor income: $\ln \left(\overline{\mathrm{Y}}_{h} / \overline{\mathrm{Y}}_{m}\right)$, just like the exogenous variables. The first endogenous variable measures the labor gap per hour each week between men and women who work full time (Mendoza-González et al. 2017).

In this model, $y_{t}$ is an NTx1 vector of the dependent variable; $\beta$ is a coefficient, and $\varepsilon_{t}$ is an error term. The model in this study uses spatial panel data. It consists of 32 cross-sectional elements (metropolitan areas) and 13 cases from 2005 to 2018. Thus, the number of observations equals $32 \times 13=416$.

It is important to highlight that the variables were generated with microdata from the ENOE: labor income, years of schooling, years of experience, hours of training, and 
labor participation are averages per metropolitan area; while variables such as the precariousness index (social benefits, wages equal to or less than two minimum wages, and non-labor and non-union contracts) as well as primary, secondary, and tertiary education were calculated, as was the employed population (or proportion) with the same characteristics, by metropolitan area.

The model in this paper uses spatial panel data. In this model, the importance of the panel data is that they capture unobservable heterogeneity, between both the economy and individuals, over time (Wooldridge 2002). This technique offers several advantages, such as the ability to control for heterogeneity and to allow for more variability. This reduces multicollinearity and provides more degrees of freedom (Baltagui 2005). The variables sometimes present spatial heterogeneity and spatial autocorrelation when we work with cross-sectional observation and spatial units (Anselin 1988), so the technique is limited and spatialization is necessary. If we incorporate the spatial lag of our variable of interest as Anselin (1988), Lesage and Pace (2009), Giuseppe (2014) and Elhorst (2014) suggest, we obtain the following equation:

$$
y_{t}=\rho \mathrm{wy}_{t}+\alpha \mathrm{lN}+\mathrm{x}_{t} \beta+\mathrm{u}_{t}
$$

where $u_{t}$ is the error component and is defined as

$$
u_{t}=\lambda w u_{t}+\varepsilon_{t}
$$

$\mathrm{IN}$ is a constant term, and $x_{t}$ are the independent variables. In this case, $\rho$ is the spatial autorregresive term, and the scalar $\lambda$ is the spatial autocorrelation term.

Within Eqs. 2 and 3, the heart of the spatial estimation is the spatial weights matrix (or connectivity matrix); its definition is crucial. $W$ is a positive square matrix; its dimension depends on the size of the data sample and describes the arrangement of possible interactions between spatial units. The elements $w_{i j}$ are the spatial weights; when there is no neighborhood they equal to 0 . The elements of the main diagonal are 0 because the possibility of self-proximity is excluded. Following Anselin (1988), each element of the matrix is defined as $w_{i j}=\left\{\begin{array}{l}1 \text { if } \mathrm{j} \in \mathrm{N}(\mathrm{i}) \\ 0 \text { if others. }\end{array}\right.$

where $N(i)$ is a series of neighbors $j$. By definition, $w_{i j}=0$, although distinct types of neighborhoods are feasible and it is possible to incorporate different types of variables that are not limited to the contiguity. Among the options, we use k-nearest neighbors. In addition to the above, Anselin (1988) suggests that the fewer neighbors a region has, the greater the individual influence they exert on the central unit. Finally, it is important to note that we are working with a normalized contiguity matrix. This implies that the sum of the rows is equal to 1 and represents a leveling of the neighbors' impacts.

Following the notation of Parajuli and Haynes (2017) and based on the values of $\rho$ and $\lambda$ different models can be specified:

If $\lambda=0$ : spatial autorregressive model (SAR)

If $\rho=0$ : spatial error model (SEM)

If $\lambda=0$ : spatial Durbin model (SDM)

If $\lambda=0, \rho=0$ : non-spatial model

The advantage of the panel data according to authors such as Wooldridge (2002), Mendoza-González and Quintana-Romero (2016), and Carbajal and De Jesús (2017), is 
that they can be interpreted through their error components. This means that the term $u_{t}$ can be decomposed in the following way:

$$
u_{i t}=c_{i}+\delta_{t}+e_{i t}
$$

where $i$ represents the individual or unit of study in cross-sectional data, $c_{i}$ represents an unobservable variable that remains constant over time for each observation (unobservable individual effect), $\delta_{t}$ represents the non-quantifiable effects that vary in time, but not between units of study, and $e_{i t}$ refers to the error term (Carbajal and De Jesús 2017). In this way, the general static panel model has two sources of heterogeneity between the cross-sectional $i$ elements: for the individual constants $c_{i}$ and for the existing individual relation parameters $\beta_{i}$ between the endogenous variable $y_{i t}$ and the exogenous variables $X_{i t}$ (Mendoza-González and Quintana-Romero 2016).

From the different assumptions about the specific effects of $c_{i}$, Carbajal and De Jesús (2017) mention three possibilities: (a) when $c_{i}=0$, which implies a lack of observable heterogeneity among individuals (pool effect); (b) when $c_{i}$ is assumed to have a fixed and different effect for each individual, so that the linear model is the same for all individuals but the intercept is specific for each; in this case, non-observable heterogeneity is included in the constant of the model; and (c) when $c_{i}$ is treated as a non-observable random variable that varies among individuals but not in time; in this case, unobservable differences are incorporated into the disturbances. As mentioned by Baltagui (2005) and Carbajal and De Jesús (2017), most applications with panel data use the error component model in one direction and assume that $\delta_{t}=0.5$.

\section{Empirical evidence}

Table 1 presents the main results of the model, by region, based on a model developed by Castro et al. (2018) and Rodríguez-Pérez and Castro-Lugo (2014). We estimated two models, to which we added variables such as schooling or education level. The estimates "total national" involve aggregate variables for Mexico's 32 metropolitan areas and for all the sectors analyzed in the work.

The results indicate that if men are more precarious than women, there is a tendency toward a reduction of the wage gap, given the negative sign of the coefficients $(-0.31$ and -0.29 in national total). This same variable was significant in the regions with medium and low influence from the opening up of commerce $(-0.31,-0.39$, and -0.34$)$.

The variables for training and experience were not statistically significant. The variable for the ratio of employed persons to men and women means that as men are more employed than women in all productive sectors, the wage gap increases, given the positive coefficients $(0.21,0.25,1.17,0.34$, and 0.93$)$. These coefficients are higher in the regions of medium and low exposure to the opening up of commerce. What this means is that in these regions, gender bias in hiring produces a detrimental effect for women, increasing wage inequality.

If we incorporate education, we find that as men increase their schooling, the wage gap increases, both for the national total and for regions with high and low exposure to the opening up of commerce $(1.45,2.69$, and 1.87$)$. This implies that the return or remuneration for schooling for men is greater than that of women, and therefore it widens Mexico's wage gap. This result is consistent with the human capital approach (Becker 1957; Aigner and Cain 1977; Becker 1981) where it has been argued that men 
Table 1 Spatial panel data estimation by region. Fixed effects, 2005-2018

\begin{tabular}{|c|c|c|c|c|c|c|c|c|}
\hline \multirow{3}{*}{$\begin{array}{l}\text { SAR models } \\
\text { Precariousness difference }\end{array}$} & \multicolumn{8}{|c|}{ Fixed effects } \\
\hline & \multicolumn{2}{|c|}{ National total } & \multicolumn{2}{|c|}{ High influence } & \multicolumn{2}{|c|}{$\begin{array}{l}\text { Medium } \\
\text { influence }\end{array}$} & \multicolumn{2}{|c|}{ Low influence } \\
\hline & $-0.31^{a}$ & $-0.29^{\mathrm{a}}$ & -0.17 & -0.29 & -0.31 & -0.27 & -0.39 & -0.34 \\
\hline & $\begin{array}{l}(- \\
3.33)\end{array}$ & $(-3.25)$ & $\begin{array}{l}(- \\
0.97)\end{array}$ & $\begin{array}{l}(- \\
1.62)\end{array}$ & $\begin{array}{l}(- \\
1.79)\end{array}$ & $\begin{array}{l}(- \\
1.62)\end{array}$ & $(-2.48)$ & $(-2.25)$ \\
\hline \multirow[t]{2}{*}{ Training difference } & $\begin{array}{l}- \\
0.003\end{array}$ & -0.006 & $-\overline{0.004}$ & 0.02 & 0.01 & -0.01 & -0.04 & -0.04 \\
\hline & $\begin{array}{l}(- \\
0.14)\end{array}$ & $(-0.29)$ & $\begin{array}{l}(- \\
0.09)\end{array}$ & $(0.39)$ & $(0.24)$ & $\begin{array}{l}(- \\
0.25)\end{array}$ & $(-1.15)$ & $(-1.19)$ \\
\hline \multirow[t]{2}{*}{ Difference in experience } & 0.19 & 0.08 & 0.17 & 0.11 & 0.12 & -0.18 & 0.36 & 0.18 \\
\hline & $(1.18)$ & $(0.47)$ & $(0.54)$ & $(0.31)$ & $(0.35)$ & $\begin{array}{l}(- \\
0.52)\end{array}$ & $(1.21)$ & $(0.58)$ \\
\hline \multirow[t]{2}{*}{ Difference in occupation } & $0.21^{\mathrm{a}}$ & 0.39 & $0.25^{c}$ & -0.14 & 0.02 & $1.17 *$ & $0.34^{a}$ & $0.93^{c}$ \\
\hline & $(2.87)$ & $(1.19)$ & $(1.74)$ & $\begin{array}{l}(- \\
0.21)\end{array}$ & $(0.16)$ & $(1.75)$ & $(2.65)$ & $(1.66)$ \\
\hline \multirow[t]{2}{*}{ Difference in education } & $1.45^{\mathrm{a}}$ & & $2.69^{a}$ & & 0.64 & & $1.87^{\mathrm{a}}$ & \\
\hline & $(4.61)$ & & (3.73) & & $(1.04)$ & & $(3.71)$ & \\
\hline \multirow[t]{2}{*}{ Difference in primary education } & & -0.12 & & 0.02 & & -0.23 & & -0.26 \\
\hline & & $(-1.36)$ & & $(0.09)$ & & $\stackrel{(-}{1.38)}$ & & $(-1.64)$ \\
\hline \multirow[t]{2}{*}{ Difference in secondary education } & & -0.31 & & -0.03 & & -0.76 & & -0.52 \\
\hline & & $(-2.34)$ & & $\begin{array}{l}(- \\
0.11)\end{array}$ & & $\begin{array}{l}(- \\
2.87)\end{array}$ & & $(-2.41)$ \\
\hline \multirow{2}{*}{$\begin{array}{l}\text { Difference in under/post-graduate } \\
\text { studies }\end{array}$} & & 0.12 & & 0.39 & & -0.44 & & -0.01 \\
\hline & & $(0.82)$ & & $(1.42)$ & & $\begin{array}{l}(- \\
1.33)\end{array}$ & & $(-0.02)$ \\
\hline \multirow[t]{2}{*}{ Rho } & $0.15^{a}$ & $0.14^{a}$ & $0.19^{b}$ & $0.21^{b}$ & 0.11 & 0.12 & 0.08 & 0.05 \\
\hline & $(2.74)$ & $(2.63)$ & $(2.26)$ & $(2.54)$ & $(1.13)$ & $(1.29)$ & $(1.22)$ & $(0.83)$ \\
\hline LM1 & $10.79^{\mathrm{a}}$ & $10.49^{\mathrm{a}}$ & $4.69^{\mathrm{a}}$ & $3.44^{\mathrm{a}}$ & $2.31^{b}$ & $3.28^{\mathrm{a}}$ & $5.33^{\mathrm{a}}$ & $4.64^{\mathrm{a}}$ \\
\hline LM2 & $4.07^{\mathrm{a}}$ & $3.00^{\mathrm{b}}$ & $2.01^{c}$ & $2.50^{\mathrm{b}}$ & 0.98 & 0.84 & $2.15^{\mathrm{b}}$ & 0.82 \\
\hline CLMlambda & $3.10^{\mathrm{a}}$ & $2.90^{\mathrm{b}}$ & 1.62 & $2.45^{\mathrm{b}}$ & 0.84 & 0.85 & 1.05 & 0.37 \\
\hline Hausman spatial & $9.69^{c}$ & 5.04 & 0.21 & $13.1^{c}$ & $112^{\mathrm{a}}$ & 4.18 & 7.63 & $16.19^{b}$ \\
\hline
\end{tabular}

a b , c Levels of significance: $1 \%, 5 \%$, and $10 \%$, respectively

$t$ statistics for each estimated coefficient are shown in parentheses

Source: Authors' extrapolation based on information from the National Survey of Occupation and Employment

earn more than women because the former obtain more formal education, they update their skills through training and they have more work experience. It also implies, however, that if women accumulate more human capital, they experience wage discrimination (Mendoza-González et al. 2017).

In such a scheme, it is expected that the variable reasons for schooling, training, and experience have positive effects on income differentials between men and women, as shown by our empirical evidence.

When we analyze the level of education, we find that only secondary education had significant parameters. This implies that if women graduate high school or finish their technical studies, they narrow the wage gap, given that the coefficients are negative and significant. This holds for both the national total and for regions that are influenced by 
medium and low trade openings $(-0.31,0.76$, and -0.52$)$. For high-exposure regions, it was not significant. The value of rho provides evidence for the spatial spillover of the wage gap. This reveals that if the wage gap increases or decreases in neighboring regions, the original region in question tends to be affected. Therefore, the labor markets of metropolitan areas that we have analyzed in this work are interconnected.

The classification at the regional level is related to regionalization, "where highexposure entities are those that, according to their rank, remained mostly in the upper third in the measures of participation of the manufacturing industries in the state GDP, foreign direct investment flows, gross census value added per capita of the manufacturing sector, percentage of employment in manufacturing over the total state employment and distance to the United States" (Rodríguez-Pérez 2018: 9) (Table 2).

With the above classification, we consider the following regions to have had high exposure: Aguascalientes, Baja California, Chihuahua, Coahuila, Estado de México, Guanajuato, Querétaro, Nuevo León, Puebla, San Luis Potosí, Sonora, and Tamaulipas. The following regions had medium exposure: Baja California Sur, Ciudad de México, Durango, Hidalgo, Jalisco, Michoacán, Morelos, Tlaxcala, Veracruz, and Zacatecas. The following regions had low exposure: Campeche, Chiapas, Colima, Guerrero, Nayarit, Oaxaca, Quintana Roo, Sinaloa, Tabasco, and Yucatán (Albani and Castro-Lugo 2016).

As in Table 1, we found that the precariousness of male labor reduced the wage gap between men and women, both at a regional level (as we saw) and in the productive sectors of Mexico's metropolitan areas. We find that these coefficients are negative for both the manufacturing sector $(-0.20,-0.32)$ and for the high-tertiary sector $(-0.47$, -0.45 ) and total services sector $(-0.25,-0.26)$. This verifies our hypothesis in the sense that male labor precariousness is one of the causes of a decrease in labor inequality in Mexico. To an even greater extent, this also affects the service sector.

Job training is only statistically significant in the high-tertiary sector. Furthermore, as men have more job training, wage inequality increases, while in the other sectors this variable was not significant. Experience is also an important factor in wage inequality. As men receive more high manufacturing and tertiary experience, their wage gap over women increases.

The proportion of employed persons or employed men is a form of gender wage discrimination. This means that when men are hired more than women (which happens in the manufacturing, high-tertiary, and service sectors), income inequality increases. Meanwhile, in the high- and low-tertiary sectors, inequality decreases.

At the sector level, we find that schooling increases the wage gap for men, given that the coefficient for all sectors is positive. University and postgraduate studies increase this inequality.

The rho variable was significant in neither the manufacturing sector nor the high- or low-tertiary sectors. It was relevant, however, when analyzing the total for the tertiary sector. This result indicates that the interrelatedness of the labor markets between MAs exists only for services. It is not a relevant process for the manufacturing industry in Mexico's MAs.

\section{Conclusions}

Previous studies, especially those similar to Mendoza-González et al. (2017), have used empirical evidence to argue that the wage gap between men and women has decreased. 
Table 2 Spatial panel data estimation by region. Fixed effects, 2005-2018

\begin{tabular}{|c|c|c|c|c|c|c|c|c|}
\hline \multirow{3}{*}{$\begin{array}{l}\text { SAR models } \\
\text { Precariousness difference }\end{array}$} & \multicolumn{8}{|c|}{ Fixed effects } \\
\hline & \multicolumn{2}{|c|}{$\begin{array}{l}\text { Manufacturing } \\
\text { sector }\end{array}$} & \multicolumn{2}{|c|}{ High tertiary } & \multicolumn{2}{|c|}{ Low tertiary } & \multicolumn{2}{|c|}{$\begin{array}{l}\text { Total tertiary } \\
\text { sector }\end{array}$} \\
\hline & $\begin{array}{l}-0.29 \\
a\end{array}$ & $\begin{array}{l}-0.32 \\
\mathrm{a}\end{array}$ & $-0.47^{\mathrm{a}}$ & $-0.45^{\mathrm{a}}$ & -0.09 & -0.09 & $-0.25^{\mathrm{a}}$ & $-0.26^{a}$ \\
\hline & $\begin{array}{l}(- \\
2.75)\end{array}$ & $\begin{array}{l}(- \\
2.96)\end{array}$ & $\begin{array}{l}(- \\
4.21)\end{array}$ & $\begin{array}{l}(- \\
4.01)\end{array}$ & $\begin{array}{l}(- \\
1.22)\end{array}$ & $(-1.26)$ & $\begin{array}{l}(- \\
2.87)\end{array}$ & $(-2.98)$ \\
\hline \multirow[t]{2}{*}{ Training difference } & 0.009 & 0.01 & $0.05^{c}$ & $0.05^{c}$ & -0.02 & -0.01 & $\begin{array}{l}- \\
0.003\end{array}$ & -0.004 \\
\hline & $(0.73)$ & $(0.71)$ & $(1.93)$ & $(1.87)$ & $\begin{array}{l}(- \\
1.08)\end{array}$ & $(-0.99)$ & $\begin{array}{l}(- \\
0.15)\end{array}$ & $(-0.19)$ \\
\hline \multirow[t]{2}{*}{ Difference in experience } & $0.39^{b}$ & $0.37^{\mathrm{b}}$ & $0.42^{b}$ & $0.38^{c}$ & 0.06 & 0.007 & 0.14 & 0.11 \\
\hline & $(2.41)$ & $(2.22)$ & $(2.05)$ & $(1.82)$ & $(0.36)$ & $(0.04)$ & $(0.82)$ & $(0.61)$ \\
\hline \multirow[t]{2}{*}{ Difference in occupation } & $0.38^{\mathrm{a}}$ & $0.46^{\mathrm{b}}$ & $0.45^{\mathrm{a}}$ & -0.23 & $\frac{-0.17}{c}$ & $\frac{-1.29}{a}$ & $0.17^{b}$ & -0.17 \\
\hline & $(3.92)$ & $(2.02)$ & $(4.51)$ & $\begin{array}{l}(- \\
0.45)\end{array}$ & $\begin{array}{l}(- \\
1.89)\end{array}$ & $(-2.65)$ & (2.19) & $(-0.35)$ \\
\hline \multirow[t]{2}{*}{ Difference in education } & $0.61^{\mathrm{b}}$ & & $1.64^{\mathrm{a}}$ & & $1.59^{\mathrm{a}}$ & & $1.61^{\mathrm{a}}$ & \\
\hline & $(2.41)$ & & $(4.41)$ & & $(5.87)$ & & $(5.35)$ & \\
\hline \multirow[t]{2}{*}{ Difference in primary education } & & -0.07 & & 0.05 & & 0.09 & & -0.02 \\
\hline & & $\begin{array}{l}(- \\
0.95)\end{array}$ & & $(0.39)$ & & $(0.91)$ & & $\begin{array}{l}(- \\
0.159)\end{array}$ \\
\hline \multirow[t]{2}{*}{ Difference in secondary education } & & -0.05 & & 0.09 & & 0.14 & & -0.08 \\
\hline & & $\begin{array}{l}(- \\
0.54)\end{array}$ & & $(0.49)$ & & $(0.87)$ & & $(-0.46)$ \\
\hline \multirow{2}{*}{$\begin{array}{l}\text { Difference in under/post-graduate } \\
\text { studies }\end{array}$} & & 0.05 & & $0.47^{\mathrm{a}}$ & & $0.78^{a}$ & & $0.38^{c}$ \\
\hline & & $(0.81)$ & & $(2.76)$ & & $(3.44)$ & & $(1.93)$ \\
\hline \multirow[t]{2}{*}{ Rho } & 0.01 & 0.01 & 0.08 & 0.07 & 0.03 & 0.04 & $0.11^{c}$ & $0.12^{b}$ \\
\hline & $(0.15)$ & $(0.17)$ & $(1.38)$ & $(1.33)$ & $(0.52)$ & $(0.77)$ & $(1.89)$ & $(2.15)$ \\
\hline LM1 & $5.57^{\mathrm{a}}$ & $4.91^{\mathrm{a}}$ & $5.45^{\mathrm{a}}$ & $5.04^{\mathrm{a}}$ & $4.32^{\mathrm{a}}$ & $3.26^{\mathrm{a}}$ & $7.57^{\mathrm{a}}$ & $6.55^{\mathrm{a}}$ \\
\hline LM2 & -0.97 & 1.00 & $1.94^{\mathrm{c}}$ & $1.88^{\mathrm{b}}$ & 0.93 & 0.84 & $2.54^{\mathrm{b}}$ & $2.1^{\mathrm{b}}$ \\
\hline CLMlambda & 0.09 & 0.05 & 1.36 & 1.43 & 0.54 & 0.75 & $1.94^{\mathrm{b}}$ & $2.17^{\mathrm{b}}$ \\
\hline Hausman spatial & $13.72^{\mathrm{b}}$ & $30.44^{\mathrm{a}}$ & 5.53 & 3.29 & $10.86^{c}$ & 11.33 & 7.83 & 3.11 \\
\hline
\end{tabular}

a, b, cLevels of significance: $1 \%, 5 \%$, and $10 \%$, respectively

$t$ statistics for each estimated coefficient are shown in parentheses

Source: Authors' extrapolation based on information from the National Survey of Occupation and Employment

They have also supported their claims with econometric models. These studies, however, do not explain that the fundamental cause of this decrease in the labor gap is the precariousness of work.

This study's most important contribution is that it shows that the labor market has played a fundamental role in job insecurity. The necessary conditions have been set so that workers do not enjoy labor protections. This gives way to outsourcing and subcontracting, resulting in men losing their wage advantage over women. We show this with different regions of high, medium, and low exposure, as well as for the productive sectors analyzed.

It should also be noted that due to a lack of space, we do not regionalize all productive sectors. We also eliminate certain sectors because job insecurity is widespread. Despite this precarious work for both men and women, we agree with Pérez et al. (2014) that wage discrimination against women exists, as they found in their 2000-2004 study. 
Our study shows that this finding holds true for the period 2005-2018. In addition, more men are employed than women, and this is more visible in regions with less exposure to international markets. In addition, in the Mexican economy, women are more skilled, in terms of education and labor experience. The female population is more likely to have both undergraduate and graduate degrees. Because of this, women's salaries equal to those of men. Note, however, that only with a university degree does the wage gap decrease, and this has been a crucial variable in reducing wage inequality. Men with basic educations, however, such as primary or secondary schooling, maintain their wage advantage.

We conclude that the international trend, in which Mexico has inserted itself, has shown that worker protections have declined; the flexibility of the labor market has led to more job precariousness. This greater precariousness for men and lessened precariousness for women turns out to be more relevant in explaining the wage differential between men and women than the factors linked to human capital (e.g., years of schooling, education level, training, or experience). This result presents a public policy dilemma: it reduces gender income inequality, but at the expense of increasing precariousness for men.

Despite diminishing the wage gap as a result of more precariousness, gender division has intensified. Women have occupied a specific job position within the Mexican economy. The conditions of supposed fragility, sensitivity, and "less work to be done" partially explain the wage gap between men and women.

Despite the labor malleability that has appeared in recent decades, both the wage gap and precariousness are lower in the manufacturing industries and the high service sector. In other sectors, precariousness was greater, and the wage gap was wider.

\section{Endnotes}

${ }^{1}$ Metropolitan zones include Ciudades de México, Guadalajara, Monterrey, Puebla, León, San Luis Potosí, Mérida, Chihuahua, Veracruz, Acapulco, Aguascalientes, Morelia, Toluca, Saltillo, Villahermosa, Tuxtla Gutiérrez, Tijuana, Culiacán, Hermosillo, Durango, Tepic, Campeche, Cuernavaca, Oaxaca, Zacatecas, Colima, Querétaro, Tlaxcala, Tampico, La Paz, Cancún, and Pachuca.

${ }^{2}$ We use the term rapports because its meaning is lost in translation when translated to "relations" in English.

${ }^{3}$ When its value approaches 1 , there is said to be a high correlation between the variables, as occurred in our case. This indicates a correlation between 0.8 and 0.9 for all periods. On the contrary, when its value approaches zero, there is a weak relationship between the variables.

${ }^{4}$ How do we know if men's salaries are higher than women's? If it is greater than 1 , men's salaries are higher; if it is less than 1, women's salaries are higher.

${ }^{5}$ For further details on traditional and spatial panel data, consult Baltagui (2005), Anselin (1988) and Elhorst (2014). 


\section{Acknowledgements}

We acknowledge The Journal of Chinese Sociology for opening interests in analyzing inequalities in a comparative perspective between China and Mexico.

\section{Authors' contributions}

RAR conducted spatial analysis, modeling, and part of theoretical analysis. MÁMG contributed equally to the analysis on modeling. LC contributed equally in conducting theoretical framework and gave the structure for the paper. All authors read and approved the final manuscript.

\section{Funding}

The authors declare no funding support

\section{Availability of data and materials}

We used ENOE data for 2005-2018 accessed at https:/www.inegi.org.mx/programas/enoe/15ymas/default.html

\section{Competing interests}

The authors declare they have no competing interests

\section{Author details}

${ }^{1}$ CONACYT-Research Fellow, National Autonomous University of Mexico, Mexico City, Mexico. ${ }^{2}$ CONACYT-SNI1, National Autonomous University of Mexico, Av. Universidad 3000, CP 04510 Mexico City, Mexico. ${ }^{3}$ Faculty of Economics, National Autonomous University of Mexico, Mexico City, Mexico.

Received: 13 December 2018 Accepted: 18 June 2019

Published online: 15 July 2019

\section{References}

Aigner, D., and G. Cain. 1977. Statistical theories of discrimination in labor markets. Industrial \& Labor Relations Review 30: 175187.

Albani, A and Castro-Lugo, D. 2016. La dinámica regional y el proceso de apertura en México, en Castro-Lugo, D and Rodríguez Pérez, RE, (ed.), Mercado laboral en México: situación y desafíos, Universidad Autónoma de Coahuila, Ediciones de Laurel, México.

Andrés-Rosales, Roldan, Carlos Bustamante-Lemus, and Giovanna Ramírez. 2018. Social exclusion and economic growth. Journal of Regional Research 40: 57-78.

Andrés-Rosales, Roldan, and M. González. 2012. El lento crecimiento manufacturero Como determinante de la precariedad laboral regional en México. 2005 a 2009. In Desarrollo y territorio. Abordajes teórico-metodológicos y expresiones socioterritoriales, 165-185. Tlaxcala: El Colegio de Tlaxcala.

Anselin, Luc. 1988. Spatial econometrics methods and models. California: Kluwer Academic Publishers.

Argy, Fred. 2007. Distribution effects of labor deregulation. Agenda 14 (2): 141-155.

Asuad, Normand. 2001. Economía Urbana y regional. Puebla: Benemérita Universidad Autónoma de Puebla.

Baltagui, Badi. 2005. Econometrics analysis of panel data. West Sussex: Wiley.

Becker, G.S. 1957. The economics of discrimination. Chicago: University of Chicago Press.

Becker, G.S. 1981. An economic theory of discrimination. In Discrimination, affirmative action, and equal opportunity, ed. W.E. Block and M.A. Walker, 129-146. Vancouver: The Fraser Institute.

Becker, Garry. 1975. Human capital: A theoretical and empirical analysis with special reference to education. Chicago: The University Press.

Bihr, Alain, and Roland Pfefferkorn. 2015. Du système d'inégalités aux classes sociales. In Bouffartigue. In Le retour des classes sociales: Inégalités, dominations, conflits, 47-63. Paris: La Dispute/SNÉDIT.

Bouffartigue, Paul. 2015. Le retour des classes sociales: Inégalités, dominations, conflits. Paris: La Dispute/SNÉDIT.

Brown, Cynthia J., José Pagan, and Eduardo Rodríguez-Oreggia. 1999. Occupational attainment an gender earning differential in Mexico. Industrial \& Labor Relations Review 53 (1): 123-135.

Caamaño, Eduardo. 2005. Las transformaciones del trabajo, la crisis de la relación laboral normal y el desarrollo del empleo atípico. Revista de Derecho 8 (1): 25-53.

Caire, Guy. 1982. Precarisation des emplois et regulation du Marche du travail. Sociologie du travai 24 (2): 135-158.

Camagni, Roberto, Roberta Capello, and Andrea Caragliu. 2015. Static vs. dynamic agglomeration economies. Spatial context. Papers in Regional Science 95 (1): 133-158.

Carbajal, Yolanda, and Leobardo De Jesús. 2017. Empleo manufacturero en la región centro de México. Una estimación por gran división. Contaduría y Administración 62: 880-901.

Castro, L. D, Rodríguez, P. R. E \& Brown, B., 2018. La brecha salarial por género y recesión económica en la Frontera norte de México. En Castro, L. D and Rodríguez, P.R.I (ed.): Mercado Laboral México y Frontera Norte. México: Universidad Autónoma de Coahuila, Ediciones de Laurel, México, pp. 46-72.

Chacon-Espejo, Susana K. and Paredes-Dusan. 2015. Desigualdad espacial de ingreso en Chile y su relación con la concentración de capital humano. El Trimestre Económico, 82(326):351-377.

Combes, Pierre-Philippe, Gilles Duranton, and Laurent Gobillon. 2008. Spatial wage disparities: Sorting matters! Journal of Urban Economics 63 (2): 723-742.

Cruz, José Nabor. 2013. Distribución del ingreso y los modelos de desarrollo en México. Mexico: Instituto de Investigaciones Económica.

Czarnecki, Lukasz. 2011a. Le salaire minimum dans la transformation néolibérale de l'État-providence au Mexique. In Revue i Interrogations? $N^{\circ} 12$ - quoi de neuf dans le salariat?

Czarnecki, Lukasz. 2011b. Le secteur informel au Mexique dans le contexte de l'Amérique Latine entre 1980-2009. Les Mondes du travail. Les Formes et les dynamiques du travail informel 9: 109-122. 
Czarnecki, Lukasz, and Vargas-Chanes Delfino. 2019. Chapter 4. Welfare regime, neoliberal transformation, and social exclusion in Mexico 1980-2015. In Social welfare responses in the neoliberal era: Policies, practices and social problems, ed. Mia Arp Fallov and Cory Blad, 72-88. Leiden and Boston: Brill.

Dela, O., E. Maria, and Cirila Quintero. 2002. Globalización, trabajo y maquilas. Las nuevas y viejas fronteras en México. Mexico: Plaza y Valdes.

Dubet, François. 2012. Classes sociales et description de la société. Revue Française de Socio-Économie 10 (2): 259-264. https:// doi.org/10.3917/rfse.010.0259.

Elhorst, Jean Paul. 2014. Spatial econometrics. From cross-sectional data to spatial panels. Heidelberg: Springer.

Farrokhi, Farid, and David Jinkins. 2015. Trade and inequality in the spatial economy.

Fernández, Dídimo Castillo, and Adrián Sotelo Valencia. 2013. Outsourcing and the new labor precariousness in Latin America. Latin American Perspectives 192 (40): 14-26.

Florida, Riczard. 2002. The rise of the creative class. Nueva York: Basic Books.

Forida, Richard, C. Mellander, K. Stolarick, and A. Ross. 2011. Cities, skills and wages. Journal of Economic Geography 12 (2): $355-377$.

Fortin, Nicole, Thomas Lemieux, and Sergio Firpo. 2011. Decomposition methods in economics. Handbook of Labor Economics 4 (1): 1-102.

García, B. 2009. Los mercados de trabajo urbano de México a principios del siglo XXI. Revista Mexicana de Sociología 71 (1): $5-46$.

Giuseppe, Arbia. 2014. A primer for spatial econometrics: With applications in R. Hampshire: Palgrave McMillan.

Glaeser, Edward. 1999. Learning in cities. Journal of Urban Economics 46 (2): 254-277.

Glaeser, Edward, and D. Mare. 2001. Cities and skills. Journal of Labor Economics 19 (2): 316-342.

Hanson, G. 2005. Globalization, labor income, and poverty in Mexico. NBER Working Paper Series: 1-50.

Jiménez, Ricardo. 1989. Participación femenina de la industria maquiladora. Cambios recientes. In Fuerza de trabajo femenina Urbana en México, participación económica y política. México: Porrúa.

Kaldor, Nicholas. 1984. Causas del lento ritmo de crecimiento del Reino Unido. Investigación Económica, XLIII 167: 9-24.

Kergoat, Danièle. 1978. Ouvriers = ouvrières? Propositions pour Une articulation théorique de deux variables: Sexe et classe sociale. Critiques de l'économie politique 5: 65-97.

Kergoat, Danièle. 2012. Se battre, disent-elles. Paris: La Dispute.

Kim, Sukkoo. 2008. Spatial inequality and economic development: Theories, facts and policies, N.P: Commission on growth and development.

Krugman, Paul. 1991. Geography and trade. Cambridge: MIT Press.

Lépinard and Lieber. 2015. Genre. In 2014. Dictionnaire des inégalités, ed. Alain Bihr and Roland Pfefferkorn, 181-183. Paris: Armand Colin.

Lesage, James, and Kelley Pace. 2009. Introduction to spatial econometrics. London: Taylor and Francis Group.

Lindley, Joanne, and D. Jinkins. 2014. Spatial changes in labor market inequality. Journal of Urban Economics 79: 121-138.

McCall, Leslie. 2001. Sources of racial wage inequality in metropolitan labor markets: Racial, ethnic, and gender differences. American Sociological Review 66 (4): 520-541.

Mendoza-González, Miguel, María Elena Cardero, and Alejandra Ortíz. 2017. Algunos hechos estilizados y explicativos sobre el diferencial y la discriminación salarial por sexo en México, 1987-2015. Investigación Económica LXXVI (301): 103-135.

Mendoza-González, Miguel, and Luis Quintana-Romero. 2016. Modelos panel y sus aplicaciones en R. In Econometría aplicada usando R. Mexico: UNAM.

Mora, Minor. 2012. La medición de la precariedad laboral: Problemas metodológicos y alternativas de solución. Trabajo 9: 87-121.

Moretti, Enrico. 2013. The new geography of jobs. Boston: Mariner Books.

Murphy, K. \& Welch, F., 1993. Inequality and relatives wages. American Economic Review 83 (2): 104-109.

Oliveira, Orlandina, and Marina Ariza. 2000. Trabajo femenino en América Latina un recuento de los principales enfoques analíticos. In Tratado Latinoamericano de sociología del trabajo, 644-663. México: El Colegio de México.

Parajuli, Jitendra, and Kingsley Haynes. 2017. Panel data models of new firm formation in New England. Region 4 (3): 65-76.

Rodríguez-Pérez, Reyna, Luis Huesca-Reynoso and Mario Camberos-Castro. 2011. Mercado laboral, inequidad salarial y cambio tecnológico regional. Frontera Norte, 23(45): 7-34.

Rodríguez-Pérez, Reyna Elizabeth 2018. Brecha salarial por género en México: Desde un enfoque regional, según su exposición a la apertura comercial 2005-2015. Noesis. Revista de Ciencias Sociales y Humanidades, 54 (27): 19-38.

Rodríguez-Pérez, Reyna Elizabeth and Castro-Lugo David. 2014. Gender wage discrimination in the labor market in Mexico and its regions. Economía Sociedad y Territorio, XIV (46): 655-686 (in Spanish).

Perramond, E. 2008. The rise, fall, and reconfiguration of the Mexican "Ejido". Geographical Review 98 (3): 356-371.

Pfefferkorn, Roland. 2016. Genre et rapports sociaux de sexe, 2. Lausanne: Éditions Page.

Porciles, Gabriele, Marcus Vinicios, and Antonio Meirelles. 2007. Technology gap, real wages, and learning in a balance-ofpayments-constrained growth model. Journal of Post Keynesian Economics 29 (3): 473-500.

Puga, Diego. 1999. The rise and fall of regional inequalities. European Economic Review 43: 303-334.

Quintana, Luis, and Blanca Garza. 2017. Desigualdad salarial y habilidades en las actividades creativas en México. In En: La economía de las actividades creativas: Una perspectiva desde España y México, 309-330. Mexico: UNAM.

Rogers, Gerry. 1989. Precarious work in Western Europe: The state of the debate. In Precarious jobs in labor market regulation: The growth of atypical employment in Western Europe, 1-16. Brussels: International Institute for labor studies and free University of Brussels.

Rojas, García Georgina, and Pérez Salas. 2008. La precarización del empleo en México, 1995-2004. Revista Latinoamericana de Estudios del Trabajo ll época 13 (19): 39-78.

Rubery, Jill. 1989. Precarious forms of work in the United Kingdom. In Precarious jobs in labor market regulation: The growth of atypical employment in Western Europe, 49-74. Ginebra: International Institute for Labor Studies.

Salvia, Agustín, and Silvana Tissera. 2000. Heterogeneidad y precarización de los hogares asalariados en Argentina. Buenos Aires: Congreso Latinoamericano de Sociología del Trabajo, ALAST.

Schultz, Theodore. 1961. Investment in human capital. The American Economic Review 51 (1): 1-17.

Standing, Guy. 1999. Global feminization through flexible labor: A theme revisited. World Development 27 (3): 583-602. 
Villamarin, Juan A., and Judith E. Villamarin. 1975. Indian labor in mainland colonial Spanish America. Newark: University of Delaware.

Wolff, Edward. 2001. Human capital investment and economic growth: Exploring the cross country evidence. Structural Change and Economic Dynamics 11 (4): 443-472.

Wolff, Edward. 2006. Does education really help? Skill, work and inequality. Oxford: Oxford University Press.

Wooldridge, Jeffrey. 2002. Econometric analysis of cross section and panel data. London: MIT Press.

Zhou, Xiaohong. 2016. Wage inequality across cities. Oslo: University of Oslo.

\section{Publisher's Note}

Springer Nature remains neutral with regard to jurisdictional claims in published maps and institutional affiliations.

Submit your manuscript to a SpringerOpen ${ }^{\circ}$ journal and benefit from:

- Convenient online submission

- Rigorous peer review

- Open access: articles freely available online

- High visibility within the field

- Retaining the copyright to your article

Submit your next manuscript at $\boldsymbol{\nabla}$ springeropen.com 